\title{
Postharvest physiology and handling of longkong fruit: A review
}

\author{
Karthikeyan Venkatachalam ${ }^{\star}$ \\ Department of Food Technology, Faculty of Science and Industrial Technology, Prince of Songkla University, Makhamtia, Muang, \\ Surat Thani 84000, Thailand
}

Received 6 April 2015 - Accepted 11 November 2015

\begin{abstract}
Introduction. Longkong fruit has a high economic value in South-East Asia, especially in Thailand. It has unique nutritional and organoleptic characteristics that contribute to fruit exports to numerous countries. Research issues. However, severe pericarp browning, fruit drop, moisture loss, off-flavor and chilling injury are the predominant problems in harvested longkong fruit during handling and storage. Temperature (low and high) and environmental conditions are the key factors that cause the majority of quality losses in longkong fruit, followed by postharvest decay. The postharvest handling of longkong fruit aims to prolong its quality and value, but it is not yet adequately developed and, as a result, several processing issues are still common. Investigated research areas. Optimal storage conditions, modified atmosphere packaging, chemical dipping and fumigation technology are widely applied to control longkong fruit postharvest losses. Although there have been numerous studies carried out on longkong fruit in the last decade, they were carried out in various countries and several languages. The present review attempts to summarise some of the most significant findings that involve fruit ripening and postharvest storage; in particular, the different treatments developed to extend the shelf life of longkong fruit.
\end{abstract}

Keywords: longkong / Aglaia dookkoo / fruit ripening / maturity stage / phenolics / postharvest technology / shelf life

Résumé - Physiologie post-récolte et manutention des fruits du longkong : Revue de synthèse. Introduction. Les fruits du longkong ont une valeur économique élevée en Asie du Sud-Est, notamment en Thaïlande. Ils ont des caractéristiques nutritionnelles et organoleptiques uniques qui contribuent aux exportations vers de nombreux pays. Problématique de recherche. Cependant, le fort brunissement du péricarpe, la chute prématurée des fruits, la perte en eau et de saveur et les blessures dues au froid sont les problèmes prédominant au cours de la manutention et du stockage des récoltes de fruits du longkong. Les températures (basse et haute) et les conditions environnementales sont les principaux facteurs qui causent la majorité des pertes de qualité du longkong, suivies par les pourritures postrécolte. La manutention post-récolte des fruits du longkong vise à prolonger leur qualité et leur valeur, mais on n'a pas encore développé de technique adéquate et, en conséquence, les problèmes de traitement sont encore monnaie courante. Axes de recherche proposés. Les conditions optimales de stockage, le conditionnement sous atmosphère modifiée, le trempage chimique et la fumigation sont des technologies largement appliquées pour réduire les pertes post-récolte du longkong. De nombreuses études ont été menées sur les fruits du longkong dans la dernière décennie, mais dans divers pays et en plusieurs langues. La présente revue tente de synthétiser quelques-unes des conclusions les plus importantes concernant le mûrissement du fruit et le stockage après récolte et en particulier les différents traitements développés pour prolonger la durée de conservation des fruits du longkong.

Mots clés : longkong / Aglaia dookkoo / mûrissement du fruit / stade de maturation / composés phénoliques / technologie post-récolte / qualité de conservation

\section{Introduction}

Longkong fruit (Aglaia dookkoo Griff.) is one of the most economically important fruits in Thailand. It is grown commercially in many other countries including Malaysia, Borneo, Vietnam, Cambodia, Myanmar, the Philippines, India, Sri

\footnotetext{
^ Corresponding author: karthikeyan.v@psu.ac.th
}

Lanka, Australia, Surinam and Puerto Rico. The export value of longkong has increased continuously due to its unique taste and pleasant aroma [1]. The United States, Hong Kong, Vietnam and Bangladesh are the major importers of longkong fruits from Thailand. Longkong fruit belongs to the Meliaceae or Mahogany family, which covers about 50 genera and 560 species, grouped taxonomically and widespread in tropical and subtropical regions [2]. Longkong is the best-known 
edible fruit species among the varieties of species in its family. Longkong fruit has a variety of names that include langsat, lanzones loong boong, kokosan duku, and duku trengganu and duku jahore [3]. Longkong fruit has many functional properties, among which the antioxidant, anti-ageing, medicinal and antimicrobial properties are the most important [4]. Rapid pericarp browning, softening and loss of freshness during transportation and in retail stores are the major problems in longkong. There has been research carried out on the postharvest quality changes in longkong fruits, but many problems still need to be rectified [5-7]. However, the available research on longkong fruit is sparse due to lack of significant information. There are several new types of research published on the extension of the postharvest life of longkong fruits, but they are in different languages [8]. The prolongation of the shelf life of longkong has not yet been accomplished due to its high susceptibility to decay and chilling injury under low temperature and higher relative humidity $(\mathrm{RH})$ storage $[9,10]$. Moreover, until now, there has been no review published on the physiological changes in longkong fruit during its maturation and postharvest storage. Therefore, the present study attempts to explore and analyse the postharvest physiology and handling of longkong fruit including numerous aspects such as changes in maturation, postharvest disorders and several postharvest technologies that are used to extend the storage life of this fruit.

\section{Physiological and biochemical changes during ripening}

\subsection{Physiological changes}

Longkong fruit (Aglaia dookkoo Griff.) is parthenocarpic and apomictic in nature. Longkong fruits are produced in bunches (25-30 fruits per bunch). The shape of longkong is globular, with a thick and leathery pericarp [11]. The pericarp color varies from dark green to bright yellow upon maturity. The matured longkong pericarp has three layers including the epicarp (outer), mesocarp (middle) and endocarp (inner). The edible portion of longkong fruit is fleshy and juicy, with five fragments of uneven white translucent adhering aril $[12,13]$ (figure 1). Longkong fruit pulp has a pleasant aroma with a sweet and slightly sour taste. The fruit has comparatively medium-sized green seeds (one to five) at maturity. The seeds are an oval shape, fertile, they germinate, and they are extremely bitter. The longkong fruit pericarp can be easily removed from the raceme end with slight applied pressure [14]. Longkong fruit has a sigmoidal growth curve from anthesis to fruit maturity. Longkong fruit grows well in the ranges of $20-30{ }^{\circ} \mathrm{C}$ and $70-80 \% \mathrm{RH}$ conditions. The fruit growth is slightly slow for the first four weeks after anthesis and afterwards, it grows rapidly up to thirteen weeks and at this stage, the fruit growth is stabilized [15]. Longkong fruit pulp is an opaque white at the $7^{\text {th }}$ week after anthesis, and it turns translucent white during the $14^{\text {th }}$ week. Longkong fruit's width, height, thickness and weight steadily increase until the $13^{\text {th }}$ week of development and after that, they are stable and almost no significant differences are observed in growth. At this stage, the fruit pulp comprises $74 \%$ of the total fruit weight, followed by the skin (24\%). The longkong fruit rind thickness is decreased, and the fruit shape changes slightly from global to spherical upon maturity [11]. Pericarp splitting is one of the main drawbacks during longkong fruit ripening. The splitting occurs due to immediate changes in the internal pressure of fruit by vast changes in the water level, temperature and humidity while ripening [16]. The rapid expansion of longkong fruit pulp beyond the resistance boundary of the pericarp could cause the pericarp splitting: it might be due to the rapid absorption of water by the roots. Splitting is highly possible when fruit reaches the maximum level of maturity $(>85 \%)$. Pericarp splitting in longkong starts at the bottom end, and then it spreads longitudinally to the stem end. Pericarp splitting exposes the longkong fruit pulp to the environment, and thus can lead to insect and fungal attacks on the fruit. It can spoil the fruit pulp and cause it to become unpalatable for human consumption [17].

Longkong is a tropical and seasonal fruit, which will not continue to ripen once picked from the tree $[1,15]$. Premature harvesting of longkong fruit can result in poor quality. Overmature longkong fruit can easily abscise from the bunches and has a short shelf life $[18,19]$. The season of longkong fruit production varies with the area. However, the greatest production of longkong in Thailand can be found between April and October every year. The changes in skin color from dark green to bright yellow are the key maturity index of longkong fruit [20]. Normally, fully matured longkong fruit pulp turns translucent white, and the astringency of the fruit tends to decrease and the sugar levels tend to increase by up to six times [21]. The maximum harvesting period of longkong is between 13 and 16 weeks after anthesis. The content of total soluble solids (TSS) is also used as a maturity indicator in longkong fruit; the recommended TSS in longkong fruit pulp during harvesting is between $15.0-17.0^{\circ}$ Brix $[13,22]$. The edible portion of longkong aril segments is arranged around a longitudinal axis with the presence of solid green seeds (figure 1). Very few studies have been reported on longkong fruit firmness during ripening. Most consumers estimate the longkong's firmness by applying a progressive compression force on the fruit with the fingers. The penetration test mostly evaluates longkong fruit firmness. The loss of firmness in longkong fruit during maturation is one of the most important factors that determines its commercial quality. Sangkasanya et al. [22] reported that longkong fruit during the medium- to the fully-ripened stage has decreasing firmness (from 1,928.3 to 1,658.8 g). Sapii et al. [12] observed a decreased in firmness from the various stages of longkong fruit ripening until senescence. Venkatachalam [17] reported that longkong fruit during maturation had increasing activities of the pectin methylesterase and polygalacturonase and this could be the reason for decreasing fruit firmness during ripening.

\subsection{Biochemical changes}

Longkong fruit is a non-climacteric fruit and during maturation it has a slightly increased respiration rate, and at a fully matured stage, the respiration rate undergoes a gradual decrease [23, 24]. Smaller-sized longkong has a higher respiration rate than larger-sized longkong [25]. Longkong fruit has 

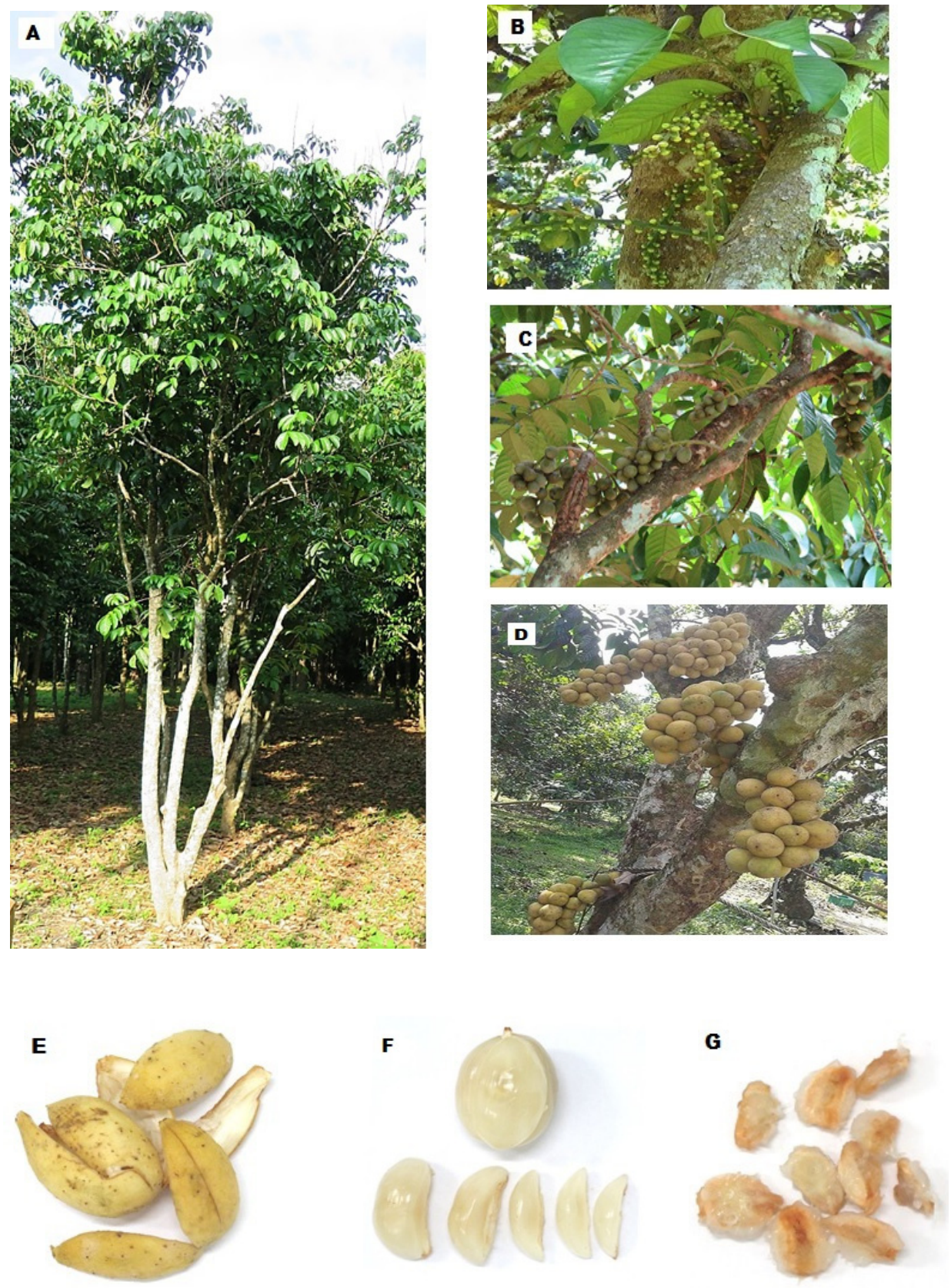

Figure 1. Examples of the longkong tree (A), immature and mature fruit (B-D), pericarp (E), fruit flesh and segments (F) and seeds (D).

a higher respiration rate $\left(224 \mathrm{mg} \mathrm{CO}_{2} \mathrm{~kg}^{-1} \mathrm{~h}^{-1}\right)$ after harvest, and then it tends to decrease $\left(206 \mathrm{mg} \mathrm{CO} \mathrm{kg}^{-1} \mathrm{~h}^{-1}\right)$ during the senescence process [8]. Additionally, longkong fruit produces a low level of ethylene in comparison with climacteric fruits. Paull et al. [1] reported longkong fruit contained a minute level of inner ethylene concentration (2 to $6 \mu \mathrm{L} \mathrm{kg}^{-1} \mathrm{~h}^{-1}$ ) during maturation. Lichanporn et al. [26] reported that the ethylene content of longkong fruit steadily increased $\left(0-1.2 \mu \mathrm{L} \mathrm{kg}^{-1} \mathrm{~h}^{-1}\right)$ during postharvest storage. However, the concentration of ethylene is different in the various regions of longkong production. Longkong is a digestive and nutritious fruit with an exceptional combination of sugar and acids [27]. Longkong fruit contents such as total soluble solids $\left(15.0-19.0^{\circ}\right.$ Brix), total sugars (13.0-14.5\%) and reducing sugars $(2.78-5.00 \%)$ increase, whereas titratable acidity tends to decrease during fruit ripening [13, 28, 29]. The primary sugars present in longkong are fructose, glucose and sucrose [30]. A gradual increase in $\mathrm{pH}(3.99-4.51)$ was observed in longkong fruit during four weeks (13 to 16 weeks) of on-tree maturation [13]. Sangkasanya et al. [22] reported that fully matured longkong fruit had a decrease in total acidity $(0.61 \%)$ as compared with immature fruit $(0.95 \%)$. Chairgulprasert et al. [31] reported that maleic acid, citric acid, malic acid and glycolic acid were the predominant organic acids observed in longkong fruit pulp. The decrease in astringency in longkong while ripening could be due to the 
Table I. Nutritional composition of longkong fruit pulp.

\begin{tabular}{|c|c|c|}
\hline Compounds & 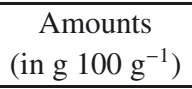 & References \\
\hline \multicolumn{3}{|l|}{ Proximate composition } \\
\hline Water $(\mathrm{g})$ & $80-85$ & {$[40,66,68]$} \\
\hline Protein $(\mathrm{g})$ & $0.9-1.0$ & {$[66,68]$} \\
\hline Total lipids (g) & 0.2 & [68] \\
\hline $\operatorname{Ash}(g)$ & 0.6 & {$[40]$} \\
\hline Crude fibre (g) & $1.5-2.5$ & {$[40,43]$} \\
\hline Carbohydrates (g) & $13-14.5$ & {$[40,66,68]$} \\
\hline \multicolumn{3}{|l|}{ Dietary fibres } \\
\hline Total dietary fibre $(\mathrm{g})$ & 0.8 & [40] \\
\hline Energy $(\mathrm{kJ})$ & 238 & [40] \\
\hline $\mathrm{pH}$ & 4.31 & [13] \\
\hline $\begin{array}{l}\text { Titratable acidity (\%) } \\
\text { as citric acid }\end{array}$ & $0.31-1.20$ & {$[13,26]$} \\
\hline \multicolumn{3}{|l|}{ Minerals } \\
\hline Sodium (mg) & 12 & {$[67]$} \\
\hline Potassium (mg) & $210-230$ & {$[40,67]$} \\
\hline Magnesium (mg) & 5 & [43] \\
\hline Calcium (mg) & $15-19$ & {$[40,43]$} \\
\hline Iron (mg) & $18-20$ & {$[40,43,66,68]$} \\
\hline Manganese (mg) & $10-10.7$ & {$[43,66]$} \\
\hline Zinc (mg) & $1.9-2.0$ & {$[43,66]$} \\
\hline Copper (mg) & 0.9 & [67] \\
\hline Phosphorous (mg) & $25-30$ & {$[40,43]$} \\
\hline \multicolumn{3}{|l|}{ Vitamins } \\
\hline Vitamin C (mg) & $3-16$ & {$[13,26]$} \\
\hline Thiamine (mcg) & 8.9 & [40] \\
\hline Riboflavin (mg) & 0.124 & [40] \\
\hline Niacin (mg) & 0.5 & [68] \\
\hline Vitamin A (I.U) & $14-15$ & {$[40,43,65]$} \\
\hline \multicolumn{3}{|l|}{ Sugar content } \\
\hline Sucrose $(\%)$ & 7.5 & [56] \\
\hline Glucose $(\%)$ & 2.8 & [56] \\
\hline Fructose $(\%)$ & 3.2 & {$[56]$} \\
\hline Total sugar $(\%)$ & $13-14.5$ & {$[13,56]$} \\
\hline Reducing sugar $(\%)$ & $3.08-5.0$ & {$[13,56]$} \\
\hline Soluble solids $\left({ }^{\circ}\right.$ Brix $)$ & 19.33 & [13] \\
\hline \multicolumn{3}{|l|}{ Organic acids } \\
\hline Maleic acid (\%) & 1.23 & [31] \\
\hline Citric acid (\%) & 0.22 & [31] \\
\hline Malic acid (\%) & 0.15 & [31] \\
\hline Glycolic acid (\%) & 0.14 & [31] \\
\hline \multicolumn{3}{|l|}{ Bioactive compounds } \\
\hline Polyphenols (g) & 5.27 & [13] \\
\hline
\end{tabular}

metabolic process [13]. On the other hand, longkong fruit contains remarkable amounts of carbohydrate, minerals and vitamins [32] (table I).

Color is the most obvious change in longkong fruit during maturation and storage [28]. During the maturation of the longkong fruit, its pericarp color changes from dark green to bright yellow, followed by changing to dark brown during postharvest storage [33]. The color changes in the longkong
Table II. List of volatile compounds identified in longkong fruit pulp.

\begin{tabular}{lc}
\hline Compounds & References \\
\hline 1,3,5 Trioxane & {$[35]$} \\
E-2-hexenel & {$[31,35]$} \\
$\alpha$-Calacorene & {$[35]$} \\
Isoledene & {$[31,35]$} \\
Copaene & {$[31,35]$} \\
Aromadendrene & {$[31,35]$} \\
$\delta$-Selinene & {$[35]$} \\
Limonene & {$[35]$} \\
Hexyl ester acetic acid & {$[35]$} \\
Phenyl ester acetic acid & {$[35]$} \\
Epizoarene & {$[35]$} \\
$\beta$-panasinsene & {$[35]$} \\
3-Carene & {$[35]$} \\
$\alpha-$ cadinol & {$[35]$} \\
$\alpha-$ elemene & {$[35]$} \\
1-Methoxy-2-propanol & {$[32,35]$} \\
Acetic acid & {$[35]$} \\
Caryophyllene & {$[31,35]$} \\
2-Phynylethyl ester acetic acid & {$[35]$} \\
Phenylethyl alcohol & {$[32,35]$} \\
(Z)-3-octene & {$[35]$} \\
Acetaldehyde & {$[32,31]$} \\
1-Methylethyl ester acetic acid & {$[32]$} \\
4-Oxo-pentanoic acid & {$[31]$} \\
Isocaryophyllene & {$[31]$} \\
2-Chloroaniline-sulfonic acid & {$[31]$} \\
3-Methylacetate-1-butanol & {$[35]$} \\
3-hydroxy-2-butanone & {$[35]$} \\
Benzaldehyde & {$[35]$} \\
Ocimene & {$[35]$} \\
Nonanol & {$[22,32,35]$} \\
Humulene & {$[22]$} \\
Linalool & {$[35]$} \\
2,4-diisoprpenyl-1-methyl-1-vinylcyclohexane \\
Fonenol & {$[35]$} \\
Torreyol & {$[35]$} \\
\hline- Muurolol & {$[35$ - } \\
\hline
\end{tabular}

pericarp are due to degradation of chlorophyll and progression of yellow tetraterpenoids during maturation [12, 23]. However, the increase in brown color during storage could be the effect of oxidoreductase enzymes [13]. An increase in redness and a decrease in lightness and yellowness was found in longkong fruit during maturation and storage [34]. Longkong has a pale white translucent pulp that covers the dark green seed. Normally, non-climacteric fruits are less flavorful than climacteric fruits. On the contrary, one of the unique properties of longkong fruit is its flavor, which contributes to its value 
Table III. Enzyme activity profiles during maturation and storage of longkong fruit.

\begin{tabular}{lccc}
\hline \multirow{2}{*}{ Enzymes } & \multicolumn{2}{c}{ Enzyme activity (units $\mathrm{mg}^{-1}$ protein) during } & \multirow{2}{*}{ References } \\
\cline { 2 - 3 } & Maturation & Storage & \\
\hline In pericarp & 23.45 & 37.85 & {$[13,26,58]$} \\
Polyphenol oxidase & 2.52 & 3.50 & {$[13,26,58]$} \\
Peroxidase & 0.51 & 0.88 & {$[13,26,58]$} \\
Phenylalanine ammonia lyase & & & \\
In fruit pulp & 21.90 & 27.55 & {$[13,49]$} \\
Superoxide dismutase & 15.17 & 13.80 & {$[13,49]$} \\
Catalase & 0.051 & 0.045 & {$[13,49]$} \\
Glutathione peroxidase & $N A^{*}$ & 8.20 & {$[49]$} \\
Lipoxygenase & 0.16 & 0.75 & {$[13,49]$} \\
Polygalacturonase & 3.04 & 2.80 & {$[13,49]$} \\
Pectin methyl esterase & & & \\
\hline
\end{tabular}

*NA: not available.

for export (table II). Longkong volatile flavor compounds are directly influenced by its maturation [22]. The volatile compounds in longkong are developed in three maturation stages: low maturity (terpenes), medium maturity (C6-alcohol) and fully matured (terpenes, ketones and phenols) [35]. Meenune et al. [32] reported that the most prominent groups of volatile compounds in longkong are sesquiterpenes $(36.23 \%)$, esters (31.88\%), hydrocarbons (4.34\%), alcohols (3.89\%), aldehydes $(2.98 \%)$, ketones $(1.44 \%)$ and furans $(1.44 \%)$. Chairgulprasert et al. [31] reported that longkong fruit sour flavor is due to maleic acid.

Very few studies have been reported on longkong fruit enzymes during maturation and storage (table III). The longkong pericarp and pulp had an increase in synthase and oxidase enzyme activities during maturation and storage $[13,36]$. Especially, the fruit pericarp contains the highest levels of phenylalanine ammonia lyase (PAL), polyphenol oxidase (PPO) and peroxidase (POD) activity and as a result, the fruit pericarp is a rich source of polyphenols and also involved in the incidence of enzymatic browning $[34,37]$. Increased activities of pectin methylesterase (PME) and polygalacturonase (PG) were observed in fully matured longkong fruit. The antioxidant enzyme activities such as superoxide dismutase (SOD), glutathione peroxidase (GPX) and catalase (CAT) activities also increased during longkong fruit maturation [17]. Fresh fruits are essential sources of bioactive compounds such as anthocyanins, vitamins, flavonoids and phenolics. Bioactive compounds exhibit potent antioxidant activity, and act against harmful diseases that are generated by the presence of free radicals [38]. Longkong fruit has been reported to be a rich source of bioactive compounds, especially polyphenolics, flavonoids and vitamins $[4,39,40]$. A fully matured longkong fruit provides a higher level of phenolics than an immature fruit. The content of phenolic compounds in longkong fruit increases with fruit maturity [17]. Also, matured longkong fruit pulp contains a large variety of vitamins such as thiamine, niacin, and vitamins A, B1, B2 and C. Vitamin C is predominant as compared with the other vitamins in longkong fruit. The different parts of longkong fruit exhibit severe inhibitory effects against several harmful diseases (table IV). Phenolics are the predominant bioactive compounds in longkong fruit.
Table IV. Medicinal properties of longkong fruit.

\begin{tabular}{lcc}
\hline Parts & \multicolumn{1}{c}{ Medicinal uses } & References \\
\hline Pericarp & $\begin{array}{c}\text { Antimalarial, antiasthma, antiageing, } \\
\text { anticancer and antibacterial activity }\end{array}$ & {$[4,69-72]$} \\
Fruit pulp & Antimalarial and anticancer activity & {$[70,73]$} \\
Seed & Antidiarrheal and antibacterial activity & {$[41,72,74]$} \\
\hline
\end{tabular}

The longkong pericarp and seeds contain more phenolics than the pulp. Also, the longkong pericarp contains a minute percentage of volatile oil, reducing acids and brown acids. The pericarp also contains secoonocerane triterpenoid glycosides, especially lansiosides (A, B and C) and onoceranoid triterpenoids [41]. Longkong seeds have sufficient levels of tetranorterpenoids, domesticulide, cerandiendione triterpenoids, germacrene $\mathrm{D}$, limonoids and kokasanolide. The extreme bitterness of longkong seeds is primarily attributed to dukolides (A, B and C) and limonoids [41,42].

\section{Postharvest disorders and treatments}

\subsection{Fruit drop}

Fruit drop from clusters is one of the most significant physiological and postharvest disorders in longkong fruit. The maximum fruit drop in longkong fruit takes place when fruit reaches the maturity level of more than $80 \%$ or in the over-mature stage. Fruit must be harvested and shipped when ripeness is around $70-80 \%$ to avoid fruit drop [1]. Longkong fruit can detach easily from clusters after 3 to 4 days of harvest, and that is mainly due to the ethylene production [3]. Also, handling such as cleaning, sorting, dipping and packing can also cause longkong fruit drop. Longkong is a non-climacteric fruit, and thus the production of ethylene is not as high as in climacteric fruits [44]. However, the minimum level of ethylene $(0.5 \mathrm{ppm})$ is sufficient to cause fruit drop from the clusters and it occurs either between the peduncle and calyx or between the calyx and fruit [6]. Pradisthakarn [45] reported that preharvested longkong fruit treated with plant hormones, primarily 
auxin, could reduce fruit drop by up to $30-35 \%$. Longkong bunches dipped in gibberellic acid at $500 \mathrm{ppm}$ for $5 \mathrm{~min}$, packed in paper cartons and stored at $13{ }^{\circ} \mathrm{C}, 90-95 \% \mathrm{RH}$, could more effectively reduce fruit drop than fruit stored in foam boxes and foam trays [46]. Taesakul et al. [6] observed that 1-methylcyclopropene treatment $\left(1 \mu \mathrm{L} \mathrm{L}^{-1}\right)$ adequately controlled longkong fruit drop and reduced the ethylene production as compared with 1-naphthaleneacetic acid (200 $\left.\mu \mathrm{L} \mathrm{L}^{-1}\right)$. Rattanapong et al. [47] reported that dipping longkong fruits in clusters in calcium chloride $(3-5 \%)$ could reduce fruit drop.

\subsection{Browning}

Longkong fruit is highly susceptible to enzymatic browning that is catalyzed by oxidoreductase enzymes such as PPO and POD [17]. Pericarp browning is one of the most significant problems in marketing and export of longkong fruit. Pericarp browning leads to the loss of economic value of longkong fruit, although it does not affect its flavor and nutritional contents [48]. Abrasion, impact injury, environmental stress and temperature fluctuations are the critical factors in generating pericarp browning in longkong fruit [34]. Additionally, the higher level of phenolic contents in longkong fruit is also a reason for pericarp browning. Longkong phenolic contents are synthesised through the phenylpropanoid pathway by the precursor enzyme PAL [37]. Longkong fruit pericarp PPO, POD and PAL enzyme activities increase during on-tree maturation, and thus induce the pericarp redness while ripening. The longkong pericarp (exocarp) contains plenty of trichomes, and it is the potent stimulator of PPO and POD activities during environmental stress conditions [13]. Storing longkong fruit at low and high temperatures causes severe pericarp browning and decreases its shelf life [49]. Storing longkong fruit at $18^{\circ} \mathrm{C}$ and 85 to $90 \%$ RH could control the rapid browning, extending the shelf life for several weeks [50,51]. Kaewsuksaeng et al. [52] reported that irradiating the longkong pericarp with ultraviolet $\mathrm{C}$ (UV-C) at $5.4 \mathrm{~kJ} \mathrm{~m}^{-2}$ noticeably controlled the browning during storage at $25{ }^{\circ} \mathrm{C}$. Venkatachalam and Meenune [37] observed that storing longkong in modified atmosphere packaging (MAP) at $25{ }^{\circ} \mathrm{C}$ could control the activities of PPO, POD and PAL in the pericarp. Lichanporn and Techavuthiporn [36] found that treating longkong fruit with $90 \%$ nitrous oxide delays the pericarp browning, and its related enzyme activities. Longkong treated with different concentrations of antibrowning agents such as citric acid (2, 4 and 6\%) and ascorbic acid (0.5 and $1.0 \%)$ and stored at $20{ }^{\circ} \mathrm{C}(90-95 \% \mathrm{RH})$ had good control of pericarp browning as compared with a lower concentration of antibrowning agents [53].

\subsection{Fruit quality loss}

Postharvest quality losses of longkong fruit are influenced by various factors such as preharvest and postharvest conditions (transportation, processing, packaging and different storage conditions (temperature and $\mathrm{RH}$ ) [30, 45, 50].
Longkong fruit is a rich source of nutrition and it is metabolically very active and sensitive during postharvest storage, thus leading to quality and nutritional losses [23]. Water is the predominant constituent (table I) in longkong fruit and storing it at an ambient temperature can rapidly increase the moisture loss [24]. Panhor et al. [54] reported that longkong fruit stored in MAP at $15{ }^{\circ} \mathrm{C}$ could last for 24 days with no more than $1 \%$ moisture loss. The sugar and organic acid contents in longkong fruit steadily decrease as the fruit storage life increases [55]. Venkatachalam [17] reported that storing longkong fruit in an oxygen transmission package at $18{ }^{\circ} \mathrm{C}$ maintained high contents of sugars and organic acids and extended the shelf life for up to 24 days. Vitamin changes in longkong fruit during storage are rarely reported. The longkong fruit ascorbic acid content increased with time during storage at a low $\left(13^{\circ} \mathrm{C}\right)$ and high temperature $\left(25^{\circ} \mathrm{C}\right)$ and at high RH $(80-90 \%)[26,56]$. Storage conditions such as the temperature and packaging environment are the key factors influencing the acidity level of postharvest longkong fruits. Longkong fruits stored in modified atmosphere packaging (MAP) and controlled atmosphere packaging (CAP) and at a high storage temperature had an increased acidity level with increased storage time. Antioxidant activity in longkong fruit is mainly contributed by the polyphenolic content $[39,57]$. The polyphenolic content in longkong pulp was found to be at a higher level in an oxygen transmission package that was stored at a high temperature $\left(25^{\circ} \mathrm{C}\right.$, $85 \% \mathrm{RH})$ as compared with that stored at a low temperature $\left(18{ }^{\circ} \mathrm{C}, 85 \% \mathrm{RH}\right)$ [51]. The prolonged storage of longkong fruit in MAP and at an ambient temperature led to a decline in the polyphenolic content in the fruit pulp [58]. Generally, a significant change can be noted in the firmness of postharvest longkong fruit during extended storage at an ambient temperature. The combination of chemical treatments and lowtemperature storage are very effective for decreasing the loss of fruit firmness during extended storage. Longkong fruit treated with methyl jasmonate (MeJA) during low-temperature storage had decreased activities of PG and PME [49]. Sangkasanya and Meenune [59] reported that storing longkong fruit in MAP $\left(10 \% \mathrm{CO}_{2}\right.$ and $\left.5 \% \mathrm{O}_{2}\right)$ at $18{ }^{\circ} \mathrm{C}$ could control the loss of fruit firmness. However, it induced ethanol accumulation in the package headspace and off-flavor formation in fruits during extended storage. Sirichote et al. [55] reported that the combination of ethylene absorbers ( 3 sachets per tray), packaging (PVC film) and room temperature $\left(18^{\circ} \mathrm{C}\right)$ storage did not differ from control conditions regarding longkong fruit firmness losses.

\subsection{Chilling injury}

Longkong fruit is highly vulnerable to very high- and lowtemperature storage as it comes from a tropical region. Although longkong fruit is more tolerant than many other tropical fruits, chilling injury occurs when it is stored at a low temperature $[14,17]$. However, until now there has been no agreement on the longkong chilling injury temperatures, which could be due to the fact that it is cultivated in different geographical regions. Several reports stated that longkong fruit stored between 10 and $15{ }^{\circ} \mathrm{C}$ had chilling injury symptoms such as fruit drop, weight loss, pitting and brown scalding 
of the skin with a water-soaked appearance $[1,44,56]$. On the other hand, Techavuthiporn and Kaewsuksaeng [14] reported that longkong fruit stored at $4{ }^{\circ} \mathrm{C}$ had chilling injury-induced pericarp browning. Venkatachalam and Meenune [9] reported that longkong fruit stored at $13{ }^{\circ} \mathrm{C}$ and $85 \% \mathrm{RH}$ for 16 days showed severe chilling-induced pericarp browning. Normally, longkong fruit chilling injury symptoms appear after fruit are kept at ambient temperature for more than three hours. A few studies were conducted to limit the severity of chilling injury in longkong fruit by using phytohormones such as MeJA. Meenune et al. [56] reported that treating longkong fruit with $20 \mu \mathrm{mol} \mathrm{L}^{-1}$ methyl jasmonate (MeJA) increased the proline content in the pericarp, which could control pericarp browning and fruit drop from clusters. Venkatachalam and Meenune [49] found that treating longkong fruit with MeJA $\left(30 \mu \mathrm{mol} \mathrm{L}{ }^{-1}\right)$ and storing it at $13{ }^{\circ} \mathrm{C}$ decreased chilling-induced pericarp ion leakage and fruit firmness loss. Additionally, MeJA could also decrease the increased enzyme activities such as pericarp PPO, PAL and POD, and fruit PG, PME and LOX.

\subsection{Fruit decay}

Longkong fruit is highly susceptible to decay as it is majorly affected by fungal and bacterial infections during postharvest storage. Sooty mould (Meliola spp.) and fruit rot (Cylindrocladium spp.) are the most common types of decay in longkong [60]. In addition, decaying organisms increased the rate of fruit drop, loss of firmness and pericarp browning in longkong [14]. Kaewsorn [61] reported that longkong fruit decay is mostly induced by Phornopsis sp., Lasiodiplodica theobromae, Fusariurn sp., Pestalotiopsis sp., Collectotrichum gloeosporioides, Nigrosprora sp., Curvularia sp., Absidia sp., Gliocladium sp. and Aspergillus sp. Seearunruangchai et al. [62] isolated the acetic acid bacteria in longkong fruit. It could induce off-flavor formation in longkong during prolonged storage at ambient temperature. Farungsang et al. [75] found that an increase in longkong fruit drop was influenced by Cladosporium, Colletotrichum, Fusarium, Lasiodiplodia and Penicillium Numerous studies were carried out to control decay in longkong fruit. Kaewsorn [61] found that treatment of longkong fruit with biofungicides (Bacillus subtilis and Trichoderma harzianurn at $10^{6}, 10^{8}$ and $10^{9} \mathrm{cfu} \mathrm{mL}^{-1}$ ) could inhibit the mycelium and spore germination. Venkatachalam [17] reported that treating longkong fruit with 500 ppm benomyl did not control the mould growth during storage at 18 and $25^{\circ} \mathrm{C}$ and $85 \%$ RH. Sangchote et al. [63] reported that the combination of hot water treatment $\left(47^{\circ} \mathrm{C}\right.$ for $3 \mathrm{~min}$ ) and dipping longkong fruit in $750 \mathrm{ppm}$ prochloraz solution for 3 min could reduce $90 \%$ of fruit rot during postharvest storage. Pithakpol et al. [64] reported that coating longkong fruit with $2 \%$ chitosan and then fumigating it with $5 \mu \mathrm{M}$ MeJA could control mould growth during postharvest storage.

\section{Processing of longkong fruit}

As mentioned above, longkong fruit spoils easily; its storage leads to rapid modifications in appearance arising from the loss of water, physiological and microbial deterioration, and pulp fermentation. Therefore, converting longkong fruit into commercial products is essential to sustain its production. However, processing longkong fruit into various products has hardly been investigated, probably due to the difficulties of separating the seeds during the process. As mentioned earlier, longkong seeds are extremely bitter and during any processing, they will affect the taste and quality, and also spoil the processing conditions and/or products. Furthermore, the longkong fruit's size and shape indirectly hinder the development of new products due to the loss of a significant amount of flesh during the removal of the seeds. Although it is difficult, there are various palatable longkong products commercially available on a small scale in Thailand. Among them, juices, jams, ice creams and sherbet are the most popular longkong products. On the other hand, longkong peel and seeds are the major byproducts after the consumption of the flesh, and they are not widely used. However, it is reported that longkong peel and seeds are rich sources of bioactivity and phytochemical components. The peel of longkong contains higher scavenging activity than the seeds, particularly when extracted with $50 \%$ aqueous ethanol and partitioned with ethyl acetate [76]. Longkong peel is rich in non-toxic oleoresin that is used against diarrhoea and fevers. However, in vitro studies showed that the peel could cause contraction of the rabbit intestine [43]. Recently, longkong peel and flesh have been used to produce cosmetics such as facial masks, facial wash gels and facial toners in Thailand. Another study proved that application of skin moisturiser and skin whitening cream containing longkong peel extract could significantly maintain the skin's moisture content and reduce the skin melanin index [40]. In addition, traditionally, the longkong pericarp is used to repel mosquitoes, and its seeds exhibit febrifugal and antifeedant activities.

\section{Conclusion}

Longkong is a non-climacteric and seasonal fruit that must be harvested when it reaches its maximum maturity index. No development occurs once the fruits are harvested or detached from the tree. Due to its unique organoleptic characteristics and nutritional properties, the demand for this fruit has increased tremendously beyond countries in Asia. However, the short shelf life of longkong fruit (3-5 days) limits its export value. The understanding of the postharvest biology and technology of longkong fruit has been rapidly developing, but is still not adequate. Longkong fruit is very sensitive to the external environment. Temperature, humidity and decay are the most important factors that decrease the shelf life of longkong fruits. Postharvest treatments and different storage conditions succeeded in extending the shelf life of longkong fruit but failed to maintain the fruit's organoleptic characteristics. The loss of quality (pericarp browning, desiccation and loss of firmness) can be partly controlled by altering the fruit's environmental conditions, which can reduce the moisture loss. Storage between 15 and $18{ }^{\circ} \mathrm{C}$ and at $85 \% \mathrm{RH}$ extends the shelf life of longkong without developing any chilling injury symptoms. The shelf life of longkong fruit could be extended 
to the maximum of 24 days with minimal organoleptic changes by using fungicide treatment, optimum atmospheric conditions and storage temperature. Longkong fruit decay is one of the main postharvest problems and $750 \mathrm{ppm}$ prochloraz, $500 \mathrm{ppm}$ benomyl and biofungicides (Bacillus subtilis and Trichoderma harzianurn) are proven to control the spoilage pathogens. Additional research is warranted for in-depth understanding of how to control visual and chemical deterioration and reduce the loss of functional and nutritional attributes in longkong. Another area to be explored is the potential use of longkong fruit in food, beverages and pharmaceutical applications.

Acknowledgements. The author expresses his sincere gratitude to Prince of Songkla University for resources and funds (No. 5107010199) to carry out this review. He is also sincerely grateful to Assistant Prof. Dr. Mutita Meenune (PSU, Hat Yai campus) for introducing this wonderful fruit to his research portfolio.

\section{References}

[1] Paull R.E., Goo T., Chen N.J., Growth and compositional changes during development of lanzone fruit, HortSci. 22 (1987) 1252-1253.

[2] Chiruvella K.K., Mohammad M., Thammineni C., Paritala V., Ghanta G.P., In vitro propagation, phytochemical investigations and biological activities of an endemic medicinal plant, Indian red wood (Meliaceae): A Review, Int. J. Med. Plant. 107 (2014) $558-571$.

[3] Salakpetch S., An overview of tropical fruit production in Thailand, in: Nagao A.M. (Ed.), Fifteenth Annual International Tropical Fruit Conference Proceedings, University of Hawaii, Hawaii, 2006.

[4] Manosroi A., Kumguan K., Chankhampan C., Manosroi W., Manosroi J., Nanoscale gelatinase A (MMP-2) inhibition on human skin fibroblasts of Longkong (Lansium domesticum Correa) leaf extracts for anti-aging, J Nanosci. Nanotechnol. 12 (2012) 7187-7197.

[5] Bunsiri A., Kunprom C., Thongbor S., Onsiri Y., Bunsiri P., Suanphairot S., Prolonging storage life of longkong under modified atmosphere, Agric. Sci. J. 33 (2002) 115-118 (English Abstract).

[6] Taesakul P., Pradisthakarn N., Chantaksinopas S., Siriphanich J., Longkong fruit abscission and its control, Posthar. Bio. Technol. 64 (2012) 91-93.

[7] Lalokkaew N., Development of coating for prolonging storage life of longkong (Lansium domesticum Corr.). Kasetsart University, Bangkok, Thesis, 2011, 178 p.

[8] Inthajak N., Sirichote A., Suanphairoch S., Puengphian C., Changes of quality and respiration rate of longkong (Lansium domesticum Corr.) fruits after harvest and at the sencescent stage, Agric. Sci. J. 42 (2011) 87-90 (English Abstract).

[9] Venkatachalam K., Meenune M., Effect of methyl jasmonate on alleviation of chilling injury in longkong fruit during storage, Agric. Sci. J. 43 (2012) 423-426.

[10] Sungsiri T., Infection biology, disease incidence and control of black mold and fruit rot on longkong fruit (Aglaia dookkoo Griff.) during pre and post-harvest. Kasetsart University, Bangkok, Thesis, 2011, 98 p.

[11] Chantaksinopas S., Kosiyachinda S., Fruit growth and development of longkong Aglaia dookkoo Griff, Kasetsart J. Natural Sci. 21 (1987) 142-150.
[12] Sapii A.T., Norila Y., Muda P., Lin T.S., Postharvest quality changes in dokong (Lansium domesticum Corr.) harvested at different stages of ripeness, in: Johnson G.I., et al. (Eds.), Quality assurance in agricultural produce, ACIAR Proceedings Australia, 2000.

[13] Venkatachalam K., Meenune M., Changes in physiochemical quality and browning related enzyme activity of longkong fruit during four different weeks of on-tree maturation, Food Chem. 131 (2012) 1437-1442.

[14] Techavuthiporn C., Kaewsuksaeng S., Quality changes of different form of minimally processed longkong at low temperature storage, Acta Hortic. 877 (2010) 635-640.

[15] Pantuvanid N., Development, postharvest index and postharvest technology of longkong, 1985.

[16] Ploetz R.C., Diseases of Tropical Fruit Crops. CABI, UK, 2003.

[17] Venkatachalam K., Changes in quality and enzymes of Longkong (Aglaia dookkoo Griff.) fruit during storages as affected by maturation, package and methyl jasmonate treatment, Prince of Songkla University, HadYai, Thesis, 2013, 180 p.

[18] Lichanporn I., Matulaprungson B., Aeamsakul N., Kanlayanarat S., Effect of gibberllic acid on fruit drop and ethylene production of longkong bunch after harvest, Agric. Sci. J. 41 (2010) 79-82 (English Abstract).

[19] Kaewtubtim P., Development of the device for optimal harvesting of longkong (Lansium domesticum Corr.) fruit clusters using physics technique, Prince of Songkla University, Hatyai, Thesis, 2009, 70 p.

[20] Sirichote A., Pisuchpen S., Jongpanyalert B., Puengphian C., Effect of maturity of stages on quality changes of longkong fruits during storage at $15 \pm 1{ }^{\circ} \mathrm{C}$, Agric. Sci. J. 44 (2013) 213-216 (English Abtract).

[21] Kittilikitsak S., Maketing, problems and obstacles of organic fruit production in the east region of Thailand. Mahidol University, Bangkok, Thesis, 2010, 157 p.

[22] Sangkasanya S., Lertsiri S., Meenune M., Changes in fruit quality and volatile flavor compounds during on-tree maturation of longkong, Int. Food Res. J. 21 (2014) 1659-1665.

[23] Siriphanich J., Postharvest physiology of tropical fruit, Acta Hortic. 575 (2002) 623-633.

[24] Lichanporn I., Srilaong V., Wongs-Aree C., Kanlayanarat S., Effect of storage temperature on peel colour and physiological changes of lonkong fruit (Aglaia dookkoo Griff.), Acta Hortic. 804 (2008) 599-604.

[25] Pastastico E.B., Mendoza D.B., Abilay R.M., Some chemical and physiological changes during storage of lanzones (Lansium domesticum Correa.), The Phillippines Agricult. 52 (1968) 505-517.

[26] Lichanporn I., Srilaong V., Wongs-Aree C., Kanlayanarat S., Postharvest physiology and browning of longkong (Aglaia dookkoo Griff.) fruit under ambient conditions, Postharvest Biol. Technol. 52 (2009) 294-299.

[27] Chareoansiri R., Kongkachuichai R., Sugar profiles and soluble and insoluble dietary fiber contents of fruits in Thailand markets, Int. J. Food Sci. Nutr. 60 (2009) 126-139.

[28] Tarmizi A.S., Norila Y., Pauziah M., Tham L.S., Changes in fruit colour and composition of dokong (Lansium domesticum Corr.) during maturation, J. Trop. Agri. Food Sci. 26 (1998) 127-133.

[29] Janhiran A., Thanapase W., Kasemsumran S., Anusornwongchai J., Brix value determination of longkong fruits using near infrared instrument, Agric. Sci. J. 41 (2010) 29-32 (English Abstract). 
[30] Sangkasanya S., Kama N., Vanakul N., Meenune M., Changes in quality of longkong for export during storage under the combination of low temperature and packaging, Agric. Sci. J. 41 (2010) 145-148 (English Abstract).

[31] Chairgulprasert V., Krisornpornsan B., Abdulhakim H., Chemical constituents of the essential oil and organic acids from longkong (Aglaia dookkoo Griff.) fruits, Songklanakarin J. Sci. Technol. 28 (2006) 321-326.

[32] Meenune M., Kama N., Vanakul N., Sangkasanya S., Characteristics of longkong (Aglaia dookkoo Griff.) and its flavour formation during on-tree maturation, Agric. Sci. J. 40 (2009) 666-669 (English Abstract).

[33] Hasimah H.A., Hasanah R.Y.M., Effect of processing treatments on the colour of dokong (Lansium domesticum Corr.) juice, J. Trop. Agric. Food Sci. 35 (2007) 281-286.

[34] Lichanporn I., Study of Browning in Longkong Fruit (Aglaia dookkoo Griff.), King Mongkut's University of Technology Thonburi, Thonburi, Thesis, 2008, 228 p.

[35] Laohakunjit N., Kerdchoechuen O., Matta B.F., Silva L.J., Holmes E.W., Postharvest survey of volatile compounds in five tropical fruits using headspeace solid phase microextraction (HS-SPME), HortSci. 42 (2007) 309-314.

[36] Lichanporn I., Techavuthiporn C., The effects of nitric oxide and nitrous oxide on enzymatic browning in longkong (Aglaia dookkoo Griff.), Postharvest Biol. Technol. 86 (2013) 62-65.

[37] Venkatachalam K., Meenune M., Effect of packaging on postharvest quality changes of longkong, Walailak J. Sci. Technol. 12 (2015) 229-236.

[38] Ho L.-H., Bhat R., Exploring the potential nutraceutical values of durian (Durio zibethinus L.) - An exotic tropical fruit, Food Chem. 168 (2015) 80-89.

[39] Lim Y.Y., Lim T.T., Tee J.J., Antioxidant properties of several tropical fruits: A comparative study, Food Chem. 103 (2007) 1003-1008.

[40] Tilaar M., Wih L.W., Ranti S.A., Wasitaatmadja S.M., Suryaningsih, Junardy D.F., Maily, Review of Lansium Domesticum Correa and its use in cosmetics, Boletín Latinoamericano y del Caribe de Plantas Medicinales y Aromáticas 7 (2008) 183-189.

[41] Mayanti T., Tjokronegoro R., Supratman U., Mukhtar M.R., Awang K., Hamid A.A., Hadi A., Antiffedant triterpenoids from the seeds and bark of Lansium domesticum cv Kokosaan (Meliaceae), Molecul. 16 (2011) 2785-2795.

[42] Lim K.T., Meliacea, in: Lim K.T. (Ed.), Edible medicinal and non medicinal plants, $3^{\text {rd }}$ Volume Springer, Netherland, 2012.

[43] Morton F.J., Langsat, in: Marton F.J. (Ed.), Fruits of warm climates, Miami, 1987.

[44] Wongs-Aree C., Noichinda S., Postharvest physiology and quality maintenance of tropical fruits, in: Prussia W.J.F.L.S.B.E. (Ed.), Postharvest handling 3rd Ed. Academic Press, San Diego, 2014.

[45] Pradisthakarn N., Effect of preharvest application of plant growth regulators on postharvest fruit drop of longkongs (Aglaia dookkoo Griff.), Kasetsart University, Nakhon Pathom, Thesis, 2011, $95 \mathrm{p}$.

[46] Matulaprungson B., Lichanporn I., Kanlayanarat S., Effect of package on reduce fruit drop of longkong, Agric. Sci. J. 39 (2008) 261-264 (English Abstract).

[47] Rattanapong J., Lim M., Sadoodee S., The effect of calcium chloride on the quality of longkong fruit Khon Kaen, Agric. J. 23 (1995) 67-73.

[48] Kaewsuksaeng S., Techavuthiporn C., Sornwisai Y., Pericarp browning alleviation and maintanence of postharvest quality of longkong (Aglaia dookkoo Griff.) by using UV-C radiation, Acta Hortic. 875 (2010) 127-132.

[49] Venkatachalam K., Meenune M., Effect of methyl jasmonate on physiological and biochemical quality changes of longkong fruit under low temperature storage, Fruits 70 (2015) 69-75.

[50] Lichanporn I., Srilaong V., Wongs-Aree C., Kanlayanarat S., External quality and physiological changes in longkong fruit during storage at various relative humidity, Acta Hortic. 4 (2008) 373-378.

[51] Venkatachalam K., Meenune M., Physical and chemical quality changes of longkong (Aglaia dookkoo Griff.) during passive modified atmospheric storage, Int. Food Res. J. 19 (2012) 795-800.

[52] Kaewsuksaeng S., Techavuthiporn C., Sornwisai Y., Effect of $\mathrm{UV}-\mathrm{C}$ radiation on biochemical changes of longkong (Aglaia dookkoo Griff) after harvesting, Acta Hortic. 875 (2010) $133-136$

[53] Lichanporn I., Techavuthiporn C., Kanlayanarat S., Effect of ascorbic acid and citric acid on browing of longkong (Aglaia dookkoo Griff.), Agric. Sci. J. 33 (2002) 119-121 (English Abstract).

[54] Panhor K., Meenune M., Manurakchinakorn S., Effect of combination of modified atmosphere and low temperature on quality of individual longkong fruit during storage, Agric. Sci. J. 39 (2008) 19-34 (English Absract).

[55] Sirichote A., Jongpanyalert B., Pisuchpen S., Rugkong A., Chanawirawan S., Puengphian C., Effect of ethylene absorber on quality of longkong (Lansium domesticum Corr.) bunches during storage, Agric. Sci. J. 42 (2011) 291-294 (English Abstract).

[56] Meenune M., Thongpanja H., Kongsuwan S., Influence of methyl jasmonate on quality changes in longkong fruit during storage under low temperature, Agric. Sci. J. 44 (2013) 257-260 (English Abstract).

[57] Tachakittirungrod S., Okonogi S., Chowwanapoonpohn S., Study on antioxidant activity of certain plants in Thailand: Mechanism of antioxidant action of guava leaf extract, Food Chem. 103 (2007) 381-388.

[58] Venkatachalam K., Meenune M., Physiological changes of longkong fruit during different storage conditions, Adv. Env. Biol. 8 (2014) 362-368.

[59] Sangkasanya S., Meenune M., Physical, chemical and sensory qualities of longkong as affected by storage at different atmospheres, Asian J. Food Agro Ind. 3 (2009) 64-74.

[60] Suanphairoch S., Lim M., Sadoodee S., Tong C., Chanawerawan S., Sirinupong M., Kananurak T., Krisornpornsan B., Develoment on production and management of longkong in the sourther region, The National Research Council of Thailand, Bangkok, 2003.

[61] Kaewsorn S., Postharvest disease of longkong and preharvest control with chemicals and biofungicides, Kasetsart University, Bangkok, Thesis, 2005, 95 p.

[62] Seearunruangchai A., Tanasupawat S., Keeratipibul S., Thawai C., Itoh T., Yamada Y., Identification of acetic acid bacteria isolated from fruits collected in Thailand, J. Gener. Appl. Microbiol. 50 (2004) 47-53.

[63] Sangchote S., Khewkhom N., Sungsiri T., Fruit rot control in longkong (Aglaia dookkoo Griff.) with chemical and hot water treatment, Acta Hortic. 943 (2012) 219-222.

[64] Pithakpol W., Soisom s., Nimitkeatkai H., Effect of methyl jasmonate fumigation and chitosan coating on postharvest quality of longkong fruits, Khon Kaen Agric. J. 42 (2014) 589-595. 
[65] Charoensiri R., Kongkachuichai R., Suknicom S., Sungpuag P., Beta-carotene, lycopene, and alpha-tocopherol contents of selected Thai fruits, Food Chem. 113 (2009) 202-207.

[66] Tee E.S., Noor M.I., Azudin M.N., Idris K., Nutrient composition of malaysian foods, Institute for Medical Research, Kuala Lumpur, 1997.

[67] Onthong J., Tirapat P., Sukmee K., Tentative standard concentration values of iron, manganese, zinc, copper and boron in Longkong (Aglaia dookkoo Griff.) Leaf, Songklanakarin J. Sci. Technol. 29 (2007) 287-293.

[68] Phantumas A., Longkong planting, Askorn Publishing Company, Bangkok, 1998.

[69] Yapp T.T.D., Y. Y.S., Lansium domesticum: skin and leaf extracts of this fruit tree interrupt the lifecycle of Plasmodium falciparum, and are active towards a chloroquine-resistant strain of the parasite (T9) in vitro, J. Ethanopharm. 85 (2003) 145-150.

[70] Solidum J., Potential nutritional and medicinal sources from fruit peels in Manila, Philippines, Int. J. BioSci. Biochem. Bioinform. 2 (2012) 270-274.

[71] Verheij E.W.M., Coronel R.E., Plant Resources of South-East Asia 2. Edible Fruits and Nuts. PROSEA, Bogor, 1992.
[72] Chaisawadi S., Keawbunrueug S., Nasakad O., Panapiyasakunchai J., Antimicrobial activities on seed and peel extracts from longkong, 37th Congress on Science and Technology of Thailand. Mahidol University, Bangkok, 2011.

[73] Manosroi A., Jantrawut P., Sainakham M., Manosroi W., Manosroi J., Anticancer activities of the extract from Longkong (Lansium domesticum) young fruits Pharm. Biol. 50 (2012) 1397-1407.

[74] Charoenrak S., Boonprasop S., Sutthirak P., Wongmongkol N., Antimicrobial activity of agricultural by-prodcuts extracts again Vibrio. spp., Thai J. Agri. Sci. 44 (2011) 200-203 (English Abstract).

[75] Farungsang N., Farungsang U., Pluemjit O., Munon Y., Sinlapasunthorn S., Fungi in association with dropped fruits of postharvest longokong: Chantaburi samples, Agric. Sci. J. 45 (3/1) (2014) 261-264 (English Abstract).

[76] Klungsupya P., Suthepakul N., Muangman T., Rerk-Am U., Thongdon-A J., Determination of free radical scavening, antioxidative DNA damage activities and phytochemical components of active fractions from Lansium domesticum Corr. fruit, Nutrients 7 (2015) 6852-6873. 